\title{
Evaluation of the Test Temperature Effect on Failure Mechanisms and Notched Impact Strength Characteristics of Ultra-Hard Low Alloy Steels
}

\author{
T. Binar, ${ }^{a, 1}$ J. Kadlec, ${ }^{b, 2}$ M. Rejzek, ${ }^{a}$ M. Vlkovsky, ${ }^{a}$ and V. Hruby ${ }^{b}$ \\ ${ }^{a}$ Department of Logistics, University of Defence, Brno, Czech Republic \\ ${ }^{\mathrm{b}}$ Department of Mechanical Engineering, University of Defence, Brno, Czech Republic \\ ${ }^{1}$ tomas.binar@unob.cz \\ 2 jaromir.kadlec@unob.cz
}

УДК 539.4

\section{Оценка влияния температуры на механизмы разрушения и характеристики ударной вязкости образцов с надрезами из высокопрочных малолегированных сталей}

\author{
Т. Бинар ${ }^{\mathrm{a}}$, Я. Кадлец ${ }^{\sigma}$, М. Рейзека ${ }^{\mathrm{a}}$, М. Влковски ${ }^{\mathrm{a}}$, В. Грубыб \\ а Отделение логистики, Университет Министерства обороны, Брно, Чехия \\ ${ }^{\sigma}$ Отделение машиностроения, Университет Министерства обороны, Брно, Чехия
}

На основании данных фрактографического анализа оченено изменение механизмов разрушения высокопрочных малолегированных сталей ARMOX 500T и ARMOX 600T в зависимости от температуры испытаний. В экспериментально исследованном температурном диапазоне -80..100 $\mathrm{C}$ была установлена высокая вероятность достижения предельного состояния этих материалов.

Ключевые слова: стали ARMOX 500T и ARMOX 600T, ударная вязкость образцов с надрезом, вязкое и квазихрупкое разрушение, температура испытаний, фрактографический анализ.

Introduction. The experimental investigation of a failure mechanism and the values of impact energy or notched impact strength is an integral part of comprehensive research in material limit states. The means of containerization are more and more often utilized in temperature ranges with significant temperature differences that can primarily cause the occurrence of degradation processes in materials leading to the occurrence of a limit state. The occurrence of a material limit state can be defined as a limit situation of balance between the effects of external influences and material response. The causes of the degradation process comprise mechanical stress and temperature. ARMOX 500T and ARMOX 600T steels are, as per, ultra-hard low alloy steels utilized according to specific needs of individual military and civil industrial branches.

1. Experimental. The experimental programme of the work concentrated on the evaluation of the influence of test temperatures on fracture surface failure mechanisms and the course of notched impact strength $K C V$ values. The value of 
notched impact strength $K C V$ was calculated from the values of measured impact energy $K V$.

1.1. Materials. Ultra-hard low alloy steel ARMOX 500T (PLATE ID NO 074218-445917) and steel ARMOX 600T (PLATE ID NO 073335-399106) were used for the experiment. The steel was supplied finally treated (after heat treatment) by the producer. Basic mechanical properties and chemical composition of the above-specified steels as per the certificate are stated in Tables 1 and 2.

T a b 1 e 1

Chemical Composition (wt.\%) of the Studied Steels

\begin{tabular}{|c|c|c|c|c|c|c|c|c|c|c||}
\hline Steel & $\mathrm{C}$ & $\mathrm{Mn}$ & $\mathrm{Si}$ & $\mathrm{Cr}$ & $\mathrm{Ni}$ & $\mathrm{Mo}$ & $\mathrm{P}$ & $\mathrm{S}$ & $\mathrm{Al}$ & $\mathrm{B}$ \\
\hline ARMOX 500T & 0.41 & 0.69 & 0.26 & 0.47 & 1.97 & 0.337 & 0.007 & 0.002 & - & 0.002 \\
\hline ARMOX 600T & 0.28 & 0.85 & 0.26 & 0.49 & 0.88 & 0.345 & 0.008 & 0.001 & 0.057 & 0.002 \\
\hline
\end{tabular}

T a b 1 e 2

Values of Basic Mechanical Properties of ARMOX Steels

\begin{tabular}{||c|c|c|c|c|c|c||}
\hline Steel & $R_{p 0.2}, \mathrm{MPa}$ & $R_{m}, \mathrm{MPa}$ & $A_{s}, \%$ & $A_{50}, \%$ & $\begin{array}{c}H B W \\
(\text { Brinell })\end{array}$ & $\begin{array}{c}K C^{*} \\
\left(-40^{\circ} \mathrm{C}\right)\end{array}$ \\
\hline ARMOX 500T & 1.399 & 1.634 & $\min 10$ & $\min 32$ & 533 & $\min 23$ \\
\hline ARMOX 600T & $* *$ & $* *$ & $* *$ & $* *$ & 632 & $\min 9$ \\
\hline
\end{tabular}

Note. * Impact test (Charpy) EN $10045-1$, test specimen $5 \times 10 \mathrm{~mm}$. ** Value is not specified in the test certificate.

1.2. Impact Test. For the impact test [1], specimens sized $(10 \times 5 \times 55 \mathrm{~mm})$ were manufactured and fitted with a V-notch $2 \mathrm{~mm}$ deep, with angle $45^{\circ}$ and radius of the notch root $\rho=0.25 \mathrm{~mm}$ (Fig. 1, Charpy-V [1]). The tests were carried out on WOLPERT PW 30/15 instrumented impact pendulum with nominal energy $300 \mathrm{~J}$. The impact velocity of the pendulum was $5.52 \mathrm{~m} / \mathrm{s}$. In case of measuring under lower temperatures, a mixture of liquid nitrogen and ethanol was used as cooling medium. Moreover, the basic characteristics, i.e., the energy consumed on the deformation and fracture of a specimen, the instrumented pendulum enabled to determine, during impact loading, the relation of power $F$ and the time $t$. The values of notched impact strength were calculated from the measured impact energy values [2, 3].

The formula for the calculation of notched impact strength value is as follows:

$$
K C V=\frac{K V}{S_{0}}\left[\mathrm{~J} / \mathrm{cm}^{2}\right],
$$

where $K V$ stands for impact energy and $S_{0}$ stands for the cross section of a rod at the point of the notch $\left(h \times b\right.$ in $\left.\mathrm{cm}^{-2}\right)$.

1.3. Fractographic Analysis. The fractographic analysis of fracture surfaces was carried out by means of a scanning electron microscope JSM 840 (JEOL), while photographs were taken in digital format using TS 12211 (TESCAN) device. 


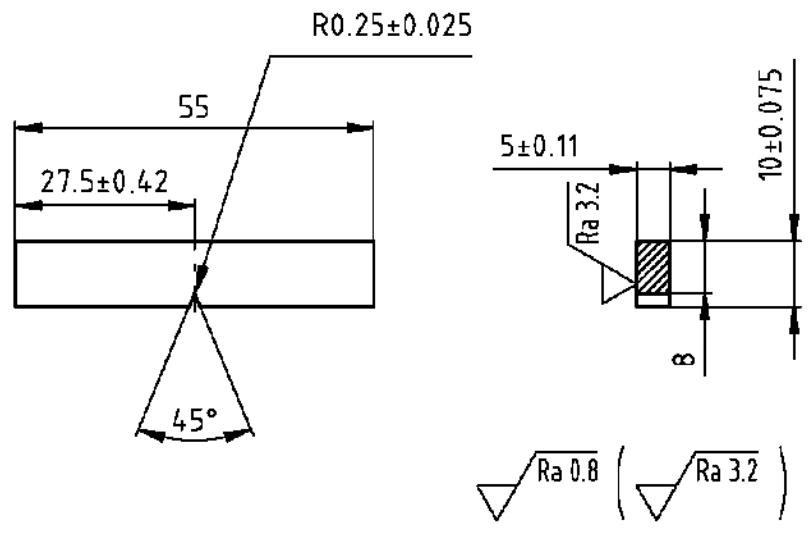

Fig. 1. Basic dimensions of a test rod (sample).

The fracture surfaces and distances were evaluated by means of a photograph analysis also using TS 12211 device. The goal of the fractographic analysis was to assess, in terms of quality, the influence of temperature on the character of fracture surfaces obtained from the notched impact strength test $[4,5]$. The morphology of fracture was photographed on individual specimens in the axis of fracture perpendicular to the notch, in the distance approx. 1/3 from the notch, applying $\times 1000$ zoom, and the greatest depth $d$ of the ductile fracture occurrence under the notch was subtracted.

\section{Results and Discussion.}

2.1 Notched Impact Strength. If $K C V$ values determined experimentally in temperature range $-80^{\circ} \mathrm{C}$ to $0^{\circ} \mathrm{C}$ are compared with values obtained at temperatures over $0^{\circ} \mathrm{C}\left(20,40,60,80\right.$, and $\left.100^{\circ} \mathrm{C}\right)$ in ARMOX 500T and ARMOX 600T steels (Tables 3 and 4), it can be said that the $K C V$ value decreases with the test temperature being bellow $0^{\circ} \mathrm{C}$. As far as ARMOX 500T steel is concerned, $K C V$ values apparently decrease at the temperature $-40^{\circ} \mathrm{C}$ (by approx. $17.6 \%$ ), $-60^{\circ} \mathrm{C}$ (by approx. $25.5 \%$ ),$-80^{\circ} \mathrm{C}$ (by approx. $32.7 \%$ ) if compared to the value of $K C V$ determined at the temperature $20^{\circ} \mathrm{C}[6,7]$. Similar decrease of $K C V$ was identified in ARMOX 600T steel (refer to Table 4). The $K C V$ values decreased at the temperature $-20^{\circ} \mathrm{C}$ (by approx. $7.1 \%$ ), $-40^{\circ} \mathrm{C}$ (by approx. $8.2 \%$ ), $-60^{\circ} \mathrm{C}$ (by approx. $12.9 \%$ ), and $-80^{\circ} \mathrm{C}$ (by approx. $23.5 \%$ ) if compared to the value determined at the temperature $20^{\circ} \mathrm{C}$.

As follows from Table 4, the $K C V$ values decrease slightly (by approx. 2.4\%) in ARMOX 600T steel at the temperature $80^{\circ} \mathrm{C}$ if compared to the $K C V$ value determined at the temperature $20^{\circ} \mathrm{C}$.

2.2. Fractographic Analysis. As discussed above, more significant decrease of the notched impact strength $K C V$ value was identified in ARMOX 500T steel if compared to ARMOX 600T steel, as in ARMOX 500T steel the decrease of the $K C V$ value at the test temperature $-80^{\circ} \mathrm{C}$ was approx. $32 \%$ if compared to the value determined at the temperature $20^{\circ} \mathrm{C}$ [8]. The failure mechanism in the lower temperature range of test temperatures was transcrystalline quasi-cleavage, in both steels. A different failure mechanism of the above-discussed steels was identified at higher temperatures (transcrystalline ductile), but no influence on the notched impact strength values has been proved. The results of the fractographic analysis 
T a b 1 e 3

The Relationship between the Impact Energy $K V$ and Notched Impact Strength $K C V$ Values and the Test Temperature (Steel ARMOX 500T)

\begin{tabular}{|c|c|c|c|c|c|}
\hline $\begin{array}{l}\text { Specimen } \\
\text { No. }\end{array}$ & $\begin{array}{l}\text { Test temperature } \\
\left({ }^{\circ} \mathrm{C}\right)\end{array}$ & \multicolumn{2}{|c|}{$\begin{array}{c}\text { Impact energy } K V 300 \\
K V, \mathrm{~J}\end{array}$} & \multicolumn{2}{|c|}{$\begin{array}{c}\text { Notched impact strength } K C V 300 \\
K C V, \mathrm{~J} / \mathrm{cm}^{2}\end{array}$} \\
\hline 1 & \multirow[t]{3}{*}{100} & 21.1 & \multirow[t]{3}{*}{$\overline{K V}=20.7$} & 52.8 & \multirow[t]{3}{*}{$\overline{K C V}=51.9$} \\
\hline 2 & & 20.8 & & 52.1 & \\
\hline 3 & & 20.3 & & 50.8 & \\
\hline 4 & \multirow[t]{3}{*}{80} & 19.9 & \multirow[t]{3}{*}{$\overline{K V}=21.0$} & 49.9 & \multirow[t]{3}{*}{$\overline{K C V}=52.6$} \\
\hline 5 & & 21.4 & & 53.5 & \\
\hline 6 & & 21.7 & & 54.3 & \\
\hline 7 & \multirow[t]{3}{*}{60} & 21.7 & \multirow[t]{3}{*}{$\overline{K V}=21.0$} & 54.3 & \multirow[t]{3}{*}{$\overline{K C V}=52.6$} \\
\hline 8 & & 21.2 & & 53.5 & \\
\hline 9 & & 20.0 & & 50.1 & \\
\hline 10 & \multirow[t]{3}{*}{40} & 21.2 & \multirow[t]{3}{*}{$\overline{K V}=21.6$} & 52.7 & \multirow[t]{3}{*}{$\overline{K C V}=53.8$} \\
\hline 11 & & 21.7 & & 54.3 & \\
\hline 12 & & 21.8 & & 54.5 & \\
\hline 13 & \multirow[t]{3}{*}{20} & 20.2 & \multirow[t]{3}{*}{$\overline{K V}=20.7$} & 50.5 & \multirow[t]{3}{*}{$\overline{K C V}=51.7$} \\
\hline 14 & & 21.4 & & 53.5 & \\
\hline 15 & & 20.4 & & 50.9 & \\
\hline 16 & \multirow[t]{3}{*}{0} & 20.6 & \multirow[t]{3}{*}{$\overline{K V}=20.4$} & 51.5 & \multirow[t]{3}{*}{$\overline{K C V}=50.9$} \\
\hline 17 & & 21.1 & & 52.7 & \\
\hline 18 & & 19.5 & & 48.6 & \\
\hline 19 & \multirow[t]{3}{*}{-20} & 20.4 & \multirow[t]{3}{*}{$\overline{K V}=20.4$} & 50.9 & \multirow[t]{3}{*}{$\overline{K C V}=50.8$} \\
\hline 20 & & 20.5 & & 51.2 & \\
\hline 21 & & 20.2 & & 50.2 & \\
\hline 22 & \multirow[t]{3}{*}{-40} & 18.4 & \multirow[t]{3}{*}{$\overline{K V}=17.6$} & 45.8 & \multirow[t]{3}{*}{$\overline{K C V}=44.0$} \\
\hline 23 & & 17.4 & & 43.4 & \\
\hline 24 & & 17.1 & & 42.8 & \\
\hline 25 & \multirow[t]{3}{*}{-60} & 16.1 & \multirow[t]{3}{*}{$\overline{K V}=15.4$} & 40.1 & \multirow[t]{3}{*}{$\overline{K C V}=38.5$} \\
\hline 26 & & 14.5 & & 36.1 & \\
\hline 27 & & 15.7 & & 39.2 & \\
\hline 28 & \multirow[t]{3}{*}{-80} & 11.5 & \multirow[t]{3}{*}{$\overline{K V}=14.0$} & 28.6 & $\overline{K C V}=34.8$ \\
\hline 29 & & 14.0 & & 35.0 & \\
\hline 30 & & 16.5 & & 40.9 & \\
\hline
\end{tabular}

show that in the zone under the notch and in the sphere along the edges of the test specimens only ductile dimple fracture mostly of shear character was identified. It follows from the below-provided fractographic analysis photographs (Figs. 2-4) that the degree of directing of fracture micromorphology grows (rolling direction applies more) with growing test temperature in specimens of ARMOX 500T steels. 
T. Binar, J. Kadlec, M. Rejzek, et al.

$\mathrm{T}$ a b 1 e 4

The Relationship between the Impact Energy $K V$ and Notched Impact Strength $K C V$ Values and the Test Temperature (Steel ARMOX 600T)

\begin{tabular}{|c|c|c|c|c|c|}
\hline $\begin{array}{c}\text { Specimen } \\
\text { No. }\end{array}$ & $\begin{array}{c}\text { Test temperature } \\
\left({ }^{\circ} \mathrm{C}\right)\end{array}$ & \multicolumn{2}{|c|}{$\begin{array}{c}\text { Impact energy } K V 300 \\
K V, \mathrm{~J}\end{array}$} & \multicolumn{2}{|c|}{$\begin{array}{c}\text { Notched impact strength } K C V 300 \\
K C V, \mathrm{~J} / \mathrm{cm}^{2}\end{array}$} \\
\hline 31 & \multirow[t]{3}{*}{100} & 9.0 & \multirow[t]{3}{*}{$\overline{K V}=9.0$} & 22.3 & \multirow[t]{3}{*}{$\overline{K C V}=22.4$} \\
\hline 32 & & 9.2 & & 22.8 & \\
\hline 33 & & 8.9 & & 22.1 & \\
\hline 34 & \multirow[t]{3}{*}{80} & 8.1 & \multirow[t]{3}{*}{$\overline{K V}=8.3$} & 20.2 & \multirow[t]{3}{*}{$\overline{K C V}=20.7$} \\
\hline 35 & & 8.4 & & 21.0 & \\
\hline 36 & & 8.4 & & 20.9 & \\
\hline 37 & \multirow[t]{3}{*}{60} & 8.8 & \multirow[t]{3}{*}{$\overline{K V}=8.9$} & 21.8 & \multirow[t]{3}{*}{$\overline{K C V}=22.1$} \\
\hline 38 & & 9.3 & & 23.1 & \\
\hline 39 & & 8.6 & & 21.4 & \\
\hline 40 & \multirow[t]{3}{*}{40} & 8.4 & \multirow[t]{3}{*}{$\overline{K V}=8.7$} & 20.9 & \multirow[t]{3}{*}{$\overline{K C V}=21.6$} \\
\hline 41 & & 8.8 & & 21.9 & \\
\hline 42 & & 8.9 & & 22.0 & \\
\hline 43 & \multirow[t]{3}{*}{20} & 8.5 & \multirow[t]{3}{*}{$\overline{K V}=8.5$} & 21.1 & \multirow[t]{3}{*}{$\overline{K C V}=21.1$} \\
\hline 44 & & 8.5 & & 21.1 & \\
\hline 45 & & 8.5 & & 21.1 & \\
\hline 46 & \multirow[t]{3}{*}{0} & 7.2 & \multirow[t]{3}{*}{$\overline{K V}=7.7$} & 18.0 & \multirow[t]{3}{*}{$\overline{K C V}=19.0$} \\
\hline 47 & & 7.7 & & 19.1 & \\
\hline 48 & & 8.1 & & 20.1 & \\
\hline 49 & \multirow[t]{3}{*}{-20} & 7.9 & \multirow[t]{3}{*}{$\overline{K V}=7.9$} & 19.6 & \multirow[t]{3}{*}{$\overline{K C V}=19.6$} \\
\hline 50 & & 8.5 & & 21.1 & \\
\hline 51 & & 7.2 & & 17.9 & \\
\hline 52 & \multirow[t]{3}{*}{-40} & 8.3 & \multirow[t]{3}{*}{$\overline{K V}=7.8$} & 20.6 & \multirow[t]{3}{*}{$\overline{K C V}=19.4$} \\
\hline 53 & & 7.5 & & 18.7 & \\
\hline 54 & & 7.6 & & 19.0 & \\
\hline 55 & \multirow[t]{3}{*}{-60} & 8.9 & \multirow[t]{3}{*}{$\overline{K V}=7.4$} & 22.0 & \multirow[t]{3}{*}{$\overline{K C V}=18.4$} \\
\hline 56 & & 6.9 & & 17.1 & \\
\hline 57 & & 6.5 & & 16.1 & \\
\hline 58 & \multirow[t]{3}{*}{-80} & 7.0 & \multirow[t]{3}{*}{$\overline{K V}=6.5$} & 17.4 & $\overline{K C V}=16.2$ \\
\hline 59 & & 6.5 & & 16.1 & \\
\hline 60 & & 6.1 & & 15.1 & \\
\hline
\end{tabular}

In ARMOX 600T steel, we can observe certain structure on the fracture surface ("the degree of directing of fracture micromorphology grows") with growing temperature. The ductile character of fracture is more common with growing temperature. 


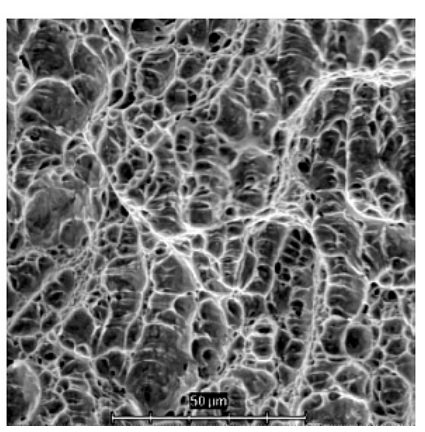

Specimen 2

$T_{Z}=100^{\circ} \mathrm{C}$

transcrystalline ductile

$d=223 \mu \mathrm{m}$

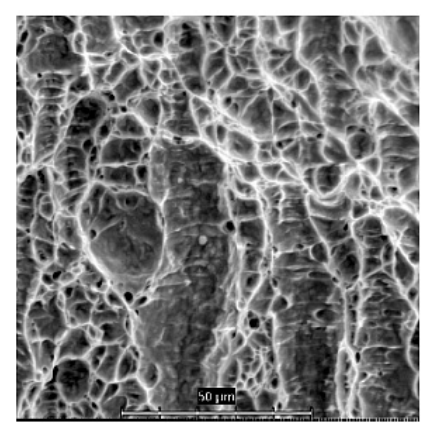

Specimen 5

$T_{Z}=80^{\circ} \mathrm{C}$

transcrystalline ductile

$d=291 \mu \mathrm{m}$

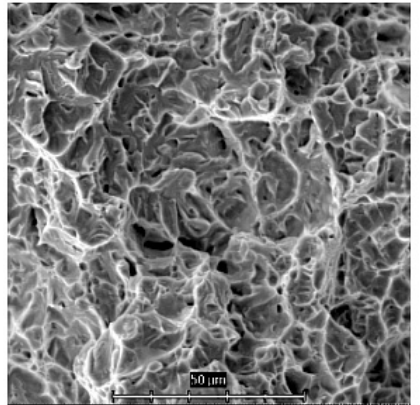

Specimen 2

$T_{Z}=-80^{\circ} \mathrm{C}$

transcrystalline ductile

$d=280 \mu \mathrm{m}$

Fig. 2. Morphology of fracture in the distance approx. 1/3 from the notch ARMOX 500T steel.

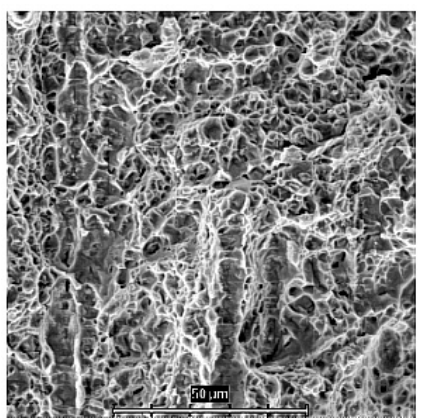

Specimen 31

$$
T_{Z}=100^{\circ} \mathrm{C}
$$

transcrystalline ductile

$$
d=213 \mu \mathrm{m}
$$

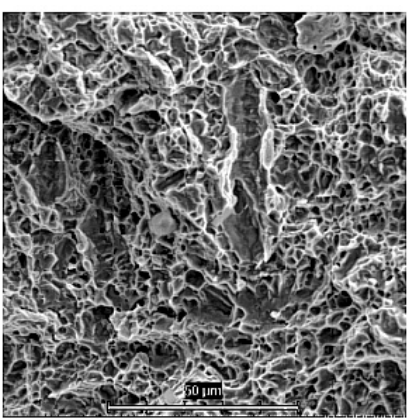

Specimen 36

$$
T_{Z}=80^{\circ} \mathrm{C}
$$

transcrystalline quasi-cleavage

$d=244 \mu \mathrm{m}$

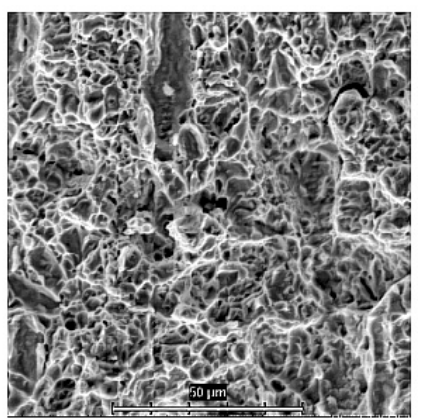

Specimen 37

$T_{Z}=60^{\circ} \mathrm{C}$

transcrystalline quasi-cleavage $d=203 \mu \mathrm{m}$

Fig. 3. Morphology of fracture in the distance approx. 1/3 from the notch ARMOX 600T steel.

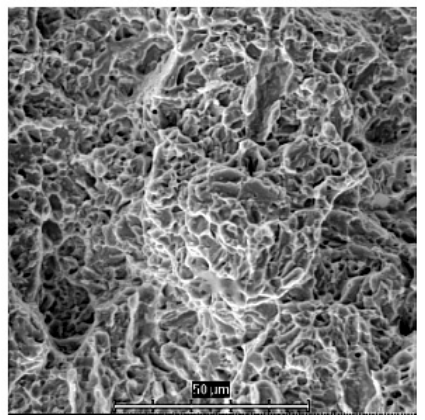

Specimen 59

$T_{Z}=-80^{\circ} \mathrm{C}$

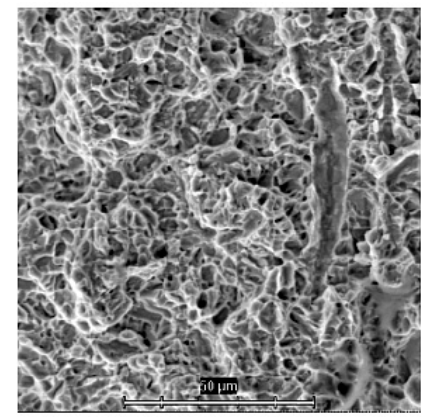

Specimen 56

$T_{Z}=-60^{\circ} \mathrm{C}$

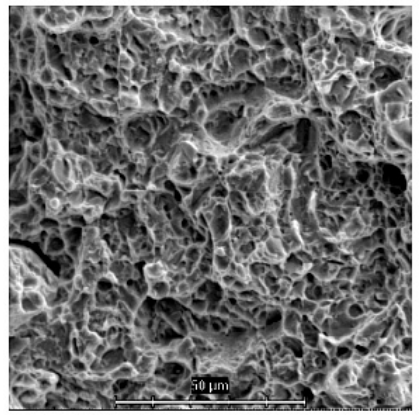

Specimen 53

$T_{Z}=-40^{\circ} \mathrm{C}$

transcrystalline quasi-cleavage transcrystalline quasi-cleavage transcrystalline quasi-cleavage

$$
d=166 \mu \mathrm{m} \quad d=133 \mu \mathrm{m} \quad d=160 \mu \mathrm{m}
$$

Fig. 4. Morphology of fracture in the distance approx. 1/3 from the notch ARMOX 600T steel. 
As shown in Fig. 5, in ARMOX 600T steel value $d$ measured at lower temperatures -80 to $0^{\circ} \mathrm{C}$ was lower as compared to values determined at the test temperatures 40 to $100^{\circ} \mathrm{C}$, and at the temperature $80^{\circ} \mathrm{C}$, when the failure mechanism is transcrystalline quasi-cleavage, there is smaller portion of ductile failure. Value $d$ measured at lower temperatures $-80,-40^{\circ} \mathrm{C}$ in ARMOX 500T steel is higher if compared to the values measured at test temperatures 80 and $100^{\circ} \mathrm{C}$. However, it has been proved, based on the fractography, that at higher test temperatures, larger structural formations of ductile failure occur than at negative temperatures. An interesting phenomenon occurs at the test temperature $80^{\circ} \mathrm{C}$, as there are larger areas of ductile failure than at the test temperature $100^{\circ} \mathrm{C}$, and the value $d$ determined is generally higher. The original hypothesis assumed that value $\mathrm{d}$ will grow in direct proportion with growing temperature, but the measurements made have disproved this hypothesis.

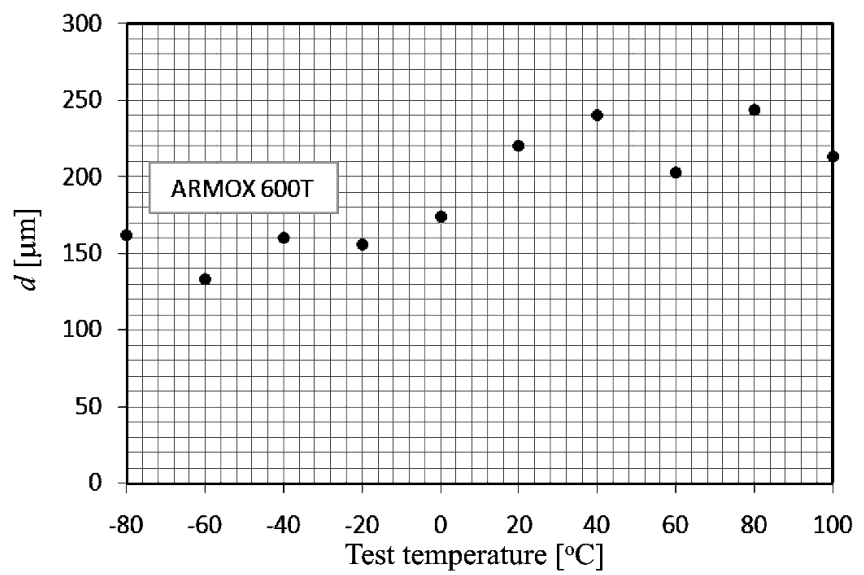

Fig. 5. The influence of test temperature $T_{Z}$ on the greatest depth $d$ of ductile fracture occurrence under the notch.

Conclusions. Part of the experimental programme was the determination of impact energy and notched impact strength values for the evaluation of the share of the above-stated quantities in the occurrence of degradation processes that directly influence a material failure mechanism.

In the set of experimental data provided, following facts can be highlighted:

(i) the evaluation of ARMOX 500T and ARMOX 600T steels fracture surfaces after the impact test proved the failure mechanism in steel ARMOX 600T to be transcrystalline quasi-cleavage and in ARMOX 500T steel to be transcrystalline ductile;

(ii) it follows from experimentally determined $K C V$ values that the values decrease significantly in both steels during experiments carried out under lower temperatures $\left(0\right.$ to $\left.-80^{\circ} \mathrm{C}\right)$. In ARMOX 500T steel specimens, it is by approx. $32 \%$, in ARMOX 600T steel specimens by approx. $24 \%$. Thus, the limits of possible occurrence of a limit state can be assumed in temperature range -80 to $-40^{\circ} \mathrm{C}$

(iii) based on the comparison of the results of fracture surface fractographic analysis carried out for both steels and determined $K C V$ values, the limit state occurrence can be quantified in temperature range -80 to $0^{\circ} \mathrm{C}$. 
Further research shall concentrate on the determination of brittle-fracture characteristics under dynamic loading of ultra-hard low alloy steels. The goal of the experiment shall be to identify the temperature ranges within which degradation processes in the material researched evolve and develop.

Acknowledgement. The work was supported by Ministry of Defence of the Czech Republic, Project No. FVT 0000404.

\section{Резиме}

На основі даних фрактографічного аналізу оцінено зміну механізмів руйнування високоміцних малолегованих сталей ARMOX 500T та ARMOX 600T y залежності від температури випробувань. В експериментально дослідженому температурному інтервалі $-80 \ldots 100^{\circ} \mathrm{C}$ установлено високу імовірність досягнення граничного стану цих матеріалів.

1. ISO 148-1:2009-Metallic Materials - Charpy Pendulum Impact Test-Part 1: Test Method, Geneva (2009).

2. H. L. Yu and D. Y. Jeong, "Application of stress-triaxiality dependent fracture criteria for unnotched Charpy specimens," in: G. C. Sih et al. (Eds.), Transferability and Applicability of Current Mechanics Approaches, ECUST, Shanghai (2009), pp. 41-51.

3. H. L. Yu and D. Y. Jeong, "Application of a stress triaxiality dependent fracture criterion in the finite element analysis of unnotched Charpy specimens," Theor. Appl. Fract. Mech., 54, 54-62 (2010).

4. T. A. Baser, C. Leinenbach, and H. J. Schindlet, "Fracture behaviour of brazed soft martensitic stainless steel joints under cyclic loading," in: L. G. Rosa and F. Margarido (Eds.), Advance Materials Forum V, TUL, Lisbon (2010), pp. 1490-1495.

5. C. Leinenbach, H. J. Schindlet, T. A. Baser, et al., "Quasistatic fracture behaviour and defect assessment of brazed soft martensitic stainless steel joints," in: J. Pokluda et. al. (Eds.), Engineering Failure Analysis, ECF 17, Brno (2010), pp. 672-682.

6. J. Man, M. Valtr, A. Weidner, et al., “AFM study of surface relief evolution in 316L steel fatigued at low and high temperatures," in: P. Lukas (Ed.), Fatigue 2010, IPM ASCR, Prague (2010), pp. 1625-1633.

7. J. Polak, T. Kruml, K. Obrtlik, et al., "Short crack growth in polycrystalline materials," in: P. Lukas (Ed.), Fatigue 2010, IPM ASCR, Prague (2010), pp. 883-892.

8. J. Hornikova, P. Sandera, J. Pokluda, "Linear-elastic and elastoplastic mode ii and iii crack tip stress-strain fields in cylindrical specimens with circumferential crack," in: M. H. Aliabadi et al. (Eds.), Advances in Fracture and Damage Mechanics VIII, FDM 09, St. George (2010). pp. 321-324. 